\title{
Temperature Conditioning and Container Size Affect Early Season Fruit Yield of Strawberry Plug Plants in a Winter, Annual Hill Production System
}

\author{
Eric B. Bish and Daniel J. Cantliffe ${ }^{1}$ \\ University of Florida, Institute of Food and Agricultural Sciences, Horticultural \\ Sciences Department, P.O. Box 110690, Gainesville, FL 32611-0690
}

\section{Craig K. Chandler}

University of Florida, Institute of Food and Agricultural Sciences, Gulf Coast Research and Education Center, 13138 Lewis Gallagher Road, Dover, FL 33527

\section{Additional index words. tray plants, Fragaria $\times$ ananassa}

\begin{abstract}
The demand for plug transplants by the Florida winter strawberry (Fragaria $\times$ ananassa Duch.) industry may increase as water conservation during plant establishment becomes more important and the loss of methyl bromide fumigant makes the production of bare-root transplants more problematic. A study was conducted during the 1995-96 and 1996-97 seasons to determine the effect of container size and temperature conditioning on the plant growth and early season fruit yield of 'Sweet Charlie' strawberry plants. Plants in containers of three sizes $\left(75,150\right.$, and $\left.300 \mathrm{~cm}^{3}\right)$ were grown in one of two temperature-controlled greenhouses $\left(35^{\circ} \mathrm{C}\right.$ day $/ 25^{\circ} \mathrm{C}$ night or $25^{\circ} \mathrm{C}$ day/15 ${ }^{\circ} \mathrm{C}$ night $)$ for the 2 weeks just prior to transplanting into a fruiting field at Dover, Fla. Plants exposed to the $25 / 15{ }^{\circ} \mathrm{C}$ treatment had significantly higher average root dry weights at planting in 1995 and 1996 than did plants exposed to the $35 / 25^{\circ} \mathrm{C}$ treatment. Plants exposed to the 25 / $15^{\circ} \mathrm{C}$ treatment also had higher average fruit yields than the plants exposed to the $35 / 25$ ${ }^{\circ} \mathrm{C}$ treatment (48\% and $18 \%$ higher in $1995-96$ and 1996-97, respectively). The effect of container size on plant growth and yield was variable. Plants propagated in the 150- and $300-\mathrm{cm}^{3}$ containers tended to be larger (at planting) than the plants propagated in the 75 $\mathrm{cm}^{3}$ containers, but the larger container sizes did not result in consistently higher yields.
\end{abstract}

Bare-root transplants with 3-4 leaves are the standard transplant used for the annual establishment of the 2500 ha of strawberries grown in west central Florida. A disadvantage of this type of transplant is that it needs extensive overhead irrigation for its successful establishment on black plastic-covered raised beds (Stanley et al., 1991). During planting in early October, Florida growers typically operate their sprinkler irrigation systems $7 \mathrm{~h}$ per day for 7 to $10 \mathrm{~d}$ to ensure plant establishment. This practice uses large amounts of water, much of which comes from the Floridan aquifer-a resource that has been severely depleted in recent years because of below average rainfall and a rapidly growing population (www.swfwmd.state.fl.us). Plug or tray transplants, in comparison to leafy bare-root transplants, require 1000 times less water for establishment (G.J. Hochmuth et al., 2001). Also, because plugs are produced using sterile potting mixes, they are less likely to have soil borne diseases, such as Phytophthora crown rot and Verticillium root rot. Bare-root trans-

Received for publication 14 May 2001. Accepted for publication 16 Oct. 2001. Florida Agricultural Experiment Station Journal Series No. R-08481. This paper represents a portion of the late Dr. Eric B. Bish's dissertation.

${ }^{1}$ To whom reprint requests should be addressed; e-mail: djcant@ufl.edu plants are produced in soil that has been fumigated to eliminate soil pathogens, but the standard fumigant used by many nurseries, methyl bromide, will no longer be available after 2005. The main disadvantage of plug plants is their high cost, which is generally double that of bare-root plants.

West central Florida has a long fruiting season (November-April), but it is usually the early season (November-February) fruit that commands the highest prices (Florida Agricultural Statistics; www.nass.usda.gov/fl). Florida and California researchers (Albregts, 1968; Chandler et al., 1989; Kirschbaum et al., 1998; Voth, 1989) have shown that high early season yields can be obtained with bare-root strawberry transplants that have large diameter crowns or have been exposed to low temperatures prior to digging. Little research has been published, however, on the influence of transplant size or pretransplant temperature on the performance of plug transplants. Durner (1999) did find that conditioned (short-day, low temperature treated) plug plants of 'Sweet Charlie' strawberry had higher December and January yield than non-conditioned plug plants, when grown in a greenhouse in New Jersey. NeSmith and Duval (1998) noted that the onset and duration of the flowering period can be affected by container size in some crops. The standard plug plant currently used in Florida has a soil volume of $\approx 75 \mathrm{~cm}^{3}$. This type of transplant, if it has a crown diameter of 8 $\mathrm{mm}$ or larger, has compared favorably with bare-root transplants, in terms of early yield (Hochmuth et al., 2001). The objective of the present study was to determine the effect of container size and pretransplant temperature on early season fruit yield of strawberry transplants grown in a winter, annual hill production system.

\section{Materials and Methods}

A $3 \times 2$ factorial experiment was conducted, with three container sizes and two preplant temperature regimes. 'Sweet Charlie' runner tips with two or three leaves and several root initials were collected from mother plants being grown in a greenhouse (Bish et al., 2001). These tips were then rooted under mist in Speedling Todd 100 plastic foam trays, and after 2 weeks transplanted on 25 July 1995 and 1996 into containers made from three different lengths of $5.4 \mathrm{~cm}$ i.d. polyvinyl chloride pipe. The three lengths were $3.25,6.5$, and 13 $\mathrm{cm}$, which corresponded to 75-, 150-, and 300$\mathrm{cm}^{3}$ container volumes. The containers were sealed on the bottom with nylon screen $(0.6$ $\mathrm{mm}$ ). The potting mix used was a mixture of 1 vermiculite : 1 perlite. Twenty-eight containers were grouped together to form an experimental unit. Water and fertilizer was supplied to the containers via capillary mats. Plants were grown for 8 weeks in a greenhouse on the campus of the Univ. of Florida in Gainesville $\left[32{ }^{\circ} \mathrm{C}\right.$ day $/ 25^{\circ} \mathrm{C}$ night; natural (long-day) photoperiod; $30 \%$ shade cloth, which resulted in an average light intensity of $700 \mu \mathrm{mol} \cdot \mathrm{m}^{-2} \cdot \mathrm{s}^{-1}$ during full sun]. On 19 Sept., 2 weeks prior to field transplanting, the plants were placed in one of two air-conditioned greenhouses. The air temperature in one of the greenhouses was maintained at $35^{\circ} \mathrm{C}$ day $/ 25$ ${ }^{\circ} \mathrm{C}$ night (to approximate ambient air temperatures in Florida) while the air temperature in the other greenhouse was maintained at $25^{\circ} \mathrm{C}$ day $/ 15^{\circ} \mathrm{C}$ night (to approximate ambient air temperatures at high elevation or high latitude nursery sites). The greenhouses were not shaded, resulting in an average light intensity of $1100 \mu \mathrm{mol} \cdot \mathrm{m}^{-2} \cdot \mathrm{s}^{-1}$ during full sun. The natural photoperiod during this 2-week period ranged from $12 \mathrm{~h} 14 \mathrm{~min}$ (19 Sept.) to $11 \mathrm{~h} 49$ $\min (3$ Oct.).

Plants were removed from the greenhouse on 3 Oct. 1995 and 1996 and transported to the Univ. of Florida's Gulf Coast Research and Education Center at Dover $(24 \mathrm{~km}$ east of Tampa), where they were planted in two-row, raised beds that had been fumigated with methyl bromide (98\%)/chloropicrin (2\%) at a rate of $269 \mathrm{~kg} \cdot \mathrm{ha}^{-1}$, and covered with black polyethylene mulch. Three replications of each of the six treatments were arranged in a randomized complete-block design. Each plot contained 20 plants, spaced $30 \mathrm{~cm}$ apart within and between rows. Plants were irrigated with overhead sprinklers for $1 \mathrm{~h}$ immediately after planting. Thereafter, drip irrigation was used. Standard cultural practices were followed throughout the season, as described by Maynard and Olson (2000). 
One plant from each plot was taken just before planting, and one 3 weeks after planting, and divided into leaves, roots, and crown. The dry weights of these tissues were recorded. Ripe fruit from the plots were harvested, graded, and weighed weekly from November through February. These data were analyzed by analysis of variance.

\section{Results and Discussion}

Preplant temperature regime did not significantly affect the crown and leaf dry weights of plants at planting, but it did influence root dry weights (Table 1). Plants exposed to the $25 / 15^{\circ} \mathrm{C}$ treatment had significantly higher average root dry weights at planting in 1995 and 1996 than did plants exposed to the $35 / 25$ ${ }^{\circ} \mathrm{C}$ treatment. These results differ from those of Kirschbaum et al. (1998), who found that the average leaf and crown, but not root, dry weight of northern-propagated bare-root 'Sweet Charlie' plants were significantly greater than those of southern-propagated plants. The average maximum/minimum air temperature for the month of September was $19 / 11^{\circ} \mathrm{C}$ in the northern propagation area and $32 / 23{ }^{\circ} \mathrm{C}$ in the southern propagation area. Any differences in root mass between northern and southern propagated plants may have been eliminated by the digging process. Plants were dug mechanically, which could have resulted in extensive root pruning.

The effect of container size on crown, leaf, and root dry weights at planting was variable (Table 1). Container size did not have an effect on crown dry weight at planting in 1995-96, but in 1996-97 plants in $300-\mathrm{cm}^{3}$ containers had greater average crown dry weight at planting than plants in smaller containers. In 1995 96 , the average leaf dry weight of the plants in $300-\mathrm{cm}^{3}$ containers was greater at planting than the average leaf dry weight of plants in smaller containers, but in 1996-97 container size had no clear effect on leaf dry weight. In 1995-96, plants in the $75-\mathrm{cm}^{3}$ containers had the lowest average root dry weight, followed by plants in the $150-\mathrm{cm}^{3}$ containers. Plants in the $300-\mathrm{cm}^{3}$ had the highest average root dry weight. In 1996-97, the average root dry weight of plants in 150 - and $300-\mathrm{cm}^{3}$ containers were similar and higher than the average root dry weight of plants in the $75-\mathrm{cm}^{3}$ containers.

Preplant temperature regime did not have an effect on the average dry weights of plants three weeks after planting in 1995-96, but did in 1996-97. Plants exposed to the $25 / 15^{\circ} \mathrm{C}$ treatment had significantly higher average crown, leaf, and root dry weights 3 weeks after planting than did plants exposed to the $35 / 25$ ${ }^{\circ} \mathrm{C}$ treatment (Table 2).

Container size had no detectable effect on the average crown and leaf dry weights of the plants 3 weeks after planting (Table 2). It did, however, affect the average root dry weight of plants exposed to the $25 / 15^{\circ} \mathrm{C}$ treatment in 1995-96. Plants that had been grown in the $300-\mathrm{cm}^{3}$ containers had significantly greater average root dry weight than plants that had been grown in the $75-$ or $150-\mathrm{cm}^{3}$ containers.

Preplant temperature regime had a signifi-

Table 1. Effect of pretransplant temperature regime and container size on strawberry crown, leaf, and root mean dry weights at the time of planting in the fruiting field. ${ }^{2}$

\begin{tabular}{|c|c|c|c|c|c|c|c|}
\hline \multirow[b]{3}{*}{ Factor } & & \multicolumn{6}{|c|}{ Dry weights (g) } \\
\hline & & \multicolumn{2}{|c|}{ Crown } & \multicolumn{2}{|c|}{ Leaf } & \multicolumn{2}{|c|}{ Root } \\
\hline & & $1995-96$ & 1996-97 & $1995-96$ & 1996-97 & 1995-96 & $1996-97$ \\
\hline \multicolumn{8}{|c|}{ Temperature regime $\left(\right.$ day/night $\left.{ }^{\circ} \mathrm{C}\right)$} \\
\hline $25 / 15$ & & & & & & $0.20 \mathrm{a}$ & $0.28 \mathrm{a}$ \\
\hline $35 / 25$ & & & & & & $0.16 \mathrm{~b}$ & $0.19 \mathrm{~b}$ \\
\hline \multicolumn{8}{|c|}{ Container size $\left(\mathrm{cm}^{3}\right)$} \\
\hline 75 & & & & $0.73 \mathrm{~b}$ & & $0.12 \mathrm{c}$ & $0.14 \mathrm{~b}$ \\
\hline 150 & & & & $0.86 \mathrm{~b}$ & & $0.17 \mathrm{~b}$ & $0.41 \mathrm{a}$ \\
\hline 300 & & & & $1.16 \mathrm{a}$ & & $0.26 \mathrm{a}$ & $0.37 \mathrm{a}$ \\
\hline \multicolumn{8}{|c|}{ Temperature $\times$ container size } \\
\hline $25 / 15$ & 75 & & $0.15 \mathrm{c}^{\mathrm{y}}$ & & $0.61 \mathrm{bc}$ & & \\
\hline $25 / 15$ & 150 & & $0.13 \mathrm{c}$ & & $0.60 \mathrm{bc}$ & & \\
\hline $25 / 15$ & 300 & & $0.23 \mathrm{~b}$ & & $0.88 \mathrm{ab}$ & & \\
\hline $35 / 25$ & 75 & & $0.07 \mathrm{~d}$ & & $0.45 \mathrm{c}$ & & \\
\hline $35 / 25$ & 150 & & $0.12 \mathrm{c}$ & & $1.03 \mathrm{a}$ & & \\
\hline \multirow[t]{2}{*}{$35 / 25$} & 300 & & $0.32 \mathrm{a}$ & & $0.82 \mathrm{ab}$ & & \\
\hline & & \multicolumn{6}{|c|}{ Significance } \\
\hline Tempe & & NS & NS & NS & NS & $* *$ & $*$ \\
\hline Contai & & NS & $* * *$ & $* * *$ & $*$ & $* * *$ & $* * *$ \\
\hline Interac & & NS & $* * *$ & NS & $*$ & NS & NS \\
\hline
\end{tabular}

${ }^{\mathrm{z}}$ Only values for significant main effects and interactions are presented.

y Mean separation within factors within columns by LSD at $P \leq 0.05$.

Ns, ***,**** Nonsignificant or significant at $P \leq 0.05,0.01$, or 0.001 , respectively.

Table 2. Effect of pretransplant temperature regime and container size on strawberry crown, leaf, and root mean dry weights 3 weeks after planting in the fruiting field. ${ }^{2}$

\begin{tabular}{|c|c|c|c|c|c|c|c|}
\hline \multirow[b]{3}{*}{ Factor } & & \multicolumn{6}{|c|}{ Dry weights $(\mathrm{g})$} \\
\hline & & \multicolumn{2}{|c|}{ Crown } & \multicolumn{2}{|c|}{ Leaf } & \multicolumn{2}{|c|}{ Root } \\
\hline & & 1995-96 & $1996-97$ & 1995-96 & $1996-97$ & 1995-96 & $1996-97$ \\
\hline \multicolumn{8}{|c|}{ Temperature regime (day/night $\left.{ }^{\circ} \mathrm{C}\right)$} \\
\hline $25 / 15$ & & & $0.28 \mathrm{a}^{\mathrm{y}}$ & & $2.30 \mathrm{a}$ & & $1.00 \mathrm{a}$ \\
\hline $35 / 25$ & & & $0.15 \mathrm{~b}$ & & $1.37 \mathrm{~b}$ & & $0.52 \mathrm{~b}$ \\
\hline \multicolumn{8}{|c|}{ Temperature $\times$ container size $\left(\mathrm{cm}^{3}\right)$} \\
\hline $25 / 15$ & 75 & & & & & $0.533 \mathrm{~b}$ & \\
\hline $25 / 15$ & 150 & & & & & $0.587 \mathrm{~b}$ & \\
\hline $25 / 15$ & 300 & & & & & $0.757 \mathrm{a}$ & \\
\hline $35 / 25$ & 75 & & & & & $0.570 \mathrm{~b}$ & \\
\hline $35 / 25$ & 150 & & & & & $0.560 \mathrm{~b}$ & \\
\hline \multirow[t]{2}{*}{$35 / 25$} & 300 & & & & & $0.567 \mathrm{~b}$ & \\
\hline & & \multicolumn{6}{|c|}{ Significance } \\
\hline \multicolumn{2}{|c|}{ Temperature } & NS & $* *$ & NS & $* *$ & NS & $* * *$ \\
\hline \multicolumn{2}{|c|}{ Container size } & NS & NS & NS & NS & $*$ & NS \\
\hline \multicolumn{2}{|c|}{ Interaction } & NS & NS & NS & NS & $*$ & NS \\
\hline
\end{tabular}

${ }^{\mathrm{z}}$ Only values for significant main effects and interactions are presented.

y Mean separation within columns by LSD at $P \leq 0.05$.

Ns, ***, **** Nonsignificant or significant at $P \leq 0.05,0.01$, or 0.001 , respectively.

cant effect on total (November through February) fruit yield (Table 3 ). Plants exposed to the $25 / 15^{\circ} \mathrm{C}$ treatment had a $48 \%$ higher average fruit yield in 1995-96 and an 18\% higher fruit yield in 1996-97 than the plants exposed to the $35 / 25^{\circ} \mathrm{C}$ treatment. These higher total yields were due to higher yields in November, December, and February. This is exactly what Kirschbaum et al. (1998) found with 'Sweet Charlie' bare-root plants. In that study, the northern-propagated plants (i.e., the plants that had been exposed to relatively low temperatures prior to transplanting) had significantly higher November-December and February yields than the southern-propagated plants.

As with plant dry weights, the effect of container size on fruit yield was variable (Table 3). In 1995-96, the total fruit yield of plants from $300-\mathrm{cm}^{3}$ containers was significantly higher than the yields of plants from $75-\mathrm{cm}^{3}$ containers, while in 1996-97, the plants from
150 and $75-\mathrm{cm}^{3}$ containers produced the highest total yields. The higher total yield of the plants from $300-\mathrm{cm}^{3}$ containers in 1995-96, compared to the yield of plants from $75-\mathrm{cm}^{3}$ containers, was due to greater fruit production in January and February.

There was a significant container size $x$ pretransplant temperature regime interaction for November and December yield in 1996-97 (Table 3). Plants from the $150-\mathrm{cm}^{3}$ containers exposed to the $25 / 15{ }^{\circ} \mathrm{C}$ temperature regime had the highest November yield, while plants from the 150 - and $75-\mathrm{cm}^{3}$ containers exposed to the $35 / 25^{\circ} \mathrm{C}$ temperature regime had the lowest November yield. These plants compensated, however, for their low November yields by producing $11 \%$ and $50 \%$ higher December yields, respectively, than their counterparts exposed to the $25 / 15^{\circ} \mathrm{C}$ temperature regime.

All transplants were exposed to the same day lengths $(\approx 12 \mathrm{~h})$ prior to transplanting- 
Table 3. Effect of pretransplant temperature regime and container size on strawberry mean fruit production. ${ }^{2}$

\begin{tabular}{|c|c|c|c|c|c|c|c|c|c|c|c|}
\hline \multirow[b]{3}{*}{ Factor } & & \multicolumn{10}{|c|}{ Marketable fruit wt $\left(\mathrm{t} \cdot \mathrm{ha}^{-1}\right)$} \\
\hline & & \multicolumn{2}{|c|}{ Nov. } & \multicolumn{2}{|c|}{ Dec. } & \multicolumn{2}{|c|}{ Jan. } & \multicolumn{2}{|c|}{ Feb. } & \multicolumn{2}{|c|}{ Total } \\
\hline & & $1995-96$ & $1996-97$ & 1995-96 & $1996-97$ & 1995-96 & $1996-97$ & 1995-96 & $1996-97$ & 1995-96 & $1996-97$ \\
\hline \multicolumn{12}{|c|}{ Temperature regime $\left(\right.$ day $/$ night $\left.^{\circ} \mathrm{C}\right)$} \\
\hline $35 / 25$ & & $0.09 \mathrm{~b}$ & & $3.82 \mathrm{~b}$ & & & & $8.01 \mathrm{~b}$ & $7.11 \mathrm{~b}$ & $14.56 \mathrm{~b}$ & $19.73 \mathrm{~b}$ \\
\hline \multicolumn{12}{|c|}{ Container size $\left(\mathrm{cm}^{3}\right)$} \\
\hline 75 & & & & & & $0.98 \mathrm{~b}$ & & $8.16 \mathrm{~b}$ & $9.80 \mathrm{a}$ & $15.68 \mathrm{~b}$ & $22.45 \mathrm{a}$ \\
\hline \multicolumn{12}{|c|}{ Temperature $\times$ container size } \\
\hline $25 / 15$ & 75 & & $2.42 \mathrm{bc}$ & & $4.35 \mathrm{~cd}$ & & & & & & \\
\hline $25 / 15$ & 150 & & $3.94 \mathrm{a}$ & & $4.50 \mathrm{~cd}$ & & & & & & \\
\hline $25 / 15$ & 300 & & $3.03 \mathrm{~b}$ & & $4.08 \mathrm{de}$ & & & & & & \\
\hline $35 / 25$ & 75 & & $0.62 \mathrm{~d}$ & & $6.53 \mathrm{a}$ & & & & & & \\
\hline $35 / 25$ & 150 & & $1.18 \mathrm{~d}$ & & $5.00 \mathrm{bc}$ & & & & & & \\
\hline $35 / 25$ & 300 & & $2.06 \mathrm{c}$ & & $3.56 \mathrm{e}$ & & & & & & \\
\hline
\end{tabular}

${ }^{2}$ Only values for significant main effects and interactions are presented.

${ }^{y}$ Mean separation within factors within columns by LSD at $P \leq 0.05$.

Ns, *,******Nonsignificant or significant at $P \leq 0.05,0.01$, or 0.001 , respectively.

day lengths that are considered conducive to floral initiation when air temperatures are between 15 and $25^{\circ} \mathrm{C}$ (Hancock, 1999). Plants exposed to the $25 / 15^{\circ} \mathrm{C}$ temperature regime began accumulating more root mass and may have begun initiating flowers during the two week treatment period, while plants exposed to the $35 / 25{ }^{\circ} \mathrm{C}$ regime did not. This would explain the higher November yields of the 25/ $15^{\circ} \mathrm{C}$ treated plants. Kirschbaum et al. (1998) notes that an adequate level of carbohydrate in the roots appears to be fundamental for early fruiting in strawberry.

The effect of container size on early season yield was less consistent than that of temperature regime. Two factors may have contributed to this inconsistency: 1) Weather differed markedly between the seasons of this study. Overall, 1995-96 was cooler and wetter than average, while 1996-97 was warmer and drier than average (Stapleton et al., 2001). 2) It was noted during the transplanting operation that some of the plants in the deeper containers did not have root systems that reached to the bottom of the container. This indicates that the plants in the deeper containers may not have had sufficient time to exploit the larger volumes of soil. Plants may need longer than 10 weeks to derive maximum benefit from a 150or $300-\mathrm{cm}^{3}$ container. Strawberry transplants for greenhouse fruit production in western Europe are grown in trays with cell sizes of 280 to $300 \mathrm{~cm}^{3}$ (Philip Lieten, personal communication). These plants typically remain in the trays for 4 months before they are transplanted into a fruit production system.

The present study has demonstrated the importance of temperature conditioning (exposure to air temperatures in the 15 to $25^{\circ} \mathrm{C}$ range) for high early season yield of strawberry plug plants grown in a winter annual hill production system. Large scale conditioning in an air-conditioned greenhouse would be impractical, but the same effect could be obtained by growing plug plants outdoors in a high elevation (e.g., western North Carolina) (Stapleton et al., 2001) or high latitude (e.g., Nova Scotia) location for several weeks (mid to late September) prior to planting in central Florida. This study has also shown that container size can affect plant growth and yield. Additional research is needed, however, to examine how factors such as length of time in the container and container shape interact with container volume to affect root and crown growth and early fruit yield.

\section{Literature Cited}

Albregts, E.E. 1968. Influence of plant size at transplanting on strawberry fruit yield. Proc. Fla. State Hort. Soc. 81:163-167.

Bish, E.B., D.J. Cantliffe, and C.K. Chandler. 2001. A system for producing large quantities of greenhouse grown strawberry plantlets for plug production. HortTechnology 11:636-638.

Chandler, C.K., E.E. Albregts, C.M. Howard, and A. Dale. 1989. Influence of propagation site on the fruiting of three strawberry clones grown in a Florida winter production system. Proc. Fla State Hort. Soc. 102:310-312.

Durner, E.F. 1999. Winter greenhouse strawberry production using conditioned plug plants. HortScience 34:615-616.

Hancock, J.F. 1999. Strawberries. CABI Publ., New York.

Hochmuth, G., C. Chandler, C. Stanley, D. Legard, J. Duval,E. Waldo, D. Cantliffe, T. Crocker, and E. Bish. 2001. Containerized transplants for establishing strawberry crops in Florida. HortScience 36:443. (Abstr.)

Kirschbaum, D.S., D.J. Cantliffe, R.L. Darnell,E.B Bish, and C.K. Chandler. 1998. Propagation site latitude influences initial carbohydrate concentration and partitioning, growth, and fruiting of 'Sweet Charlie' strawberry transplants grown in Florida. Proc. Fla. State Hort. Soc. 111:93-96.

Maynard, D.N. and S.M. Olson (eds.). 2000. Vegetable production guide for Florida (SP170). Univ. of Florida and Citrus and Veg. Mag.

NeSmith, D.S. and J.R. Duval. 1998. The effect of container size (in the proceedings of the workshop on transplant production and performance). HortTechnology 8:495-498.

Stanley, C.D., G.A. Clark, E.E. Albregts, and F.S. Zazueta. 1991. Reduction of deep aquifer withdrawals and runoff for overhead-irrigated strawberry production using a runoff recovery system. Appl. Eng. Agr. 7:205-208.

Stapleton, S.C., C.K. Chandler, D.E. Legard, J.F. Price, and J.C. Sumler. 2001. Transplant source affects fruiting performance and pests of 'Sweet Charlie' strawberry in Florida. HortTechnology 11:61-65.

Voth, V. 1989. The effect of nursery location latitude on California winter planted strawberries. Acta Hort. 265:283-284. 